\title{
DETERMINATION OF THE CAUSE OF THE FORMATION OF TRANSVERSE INTERNAL CRACKS ON A CONTINUOUSLY CAST SLAB
}

\author{
UGOTAVLJANJE VZROKOV ZA NASTANEK NOTRANJIH \\ PREČNIH RAZPOK V KONTINUIRNO ULITEM SLABU
}

\author{
Zdeněk Franěk $^{1}$, Miloš Masarik ${ }^{2}$, Jaromír Šmíd ${ }^{3}$ \\ ${ }^{1}$ Silesian University in Opava, School of Business Administration in Karvina, Univerzitní nám. 1934/3, 73340 Karviná, Czech Republic \\ 2VITKOVICE STEEL, a.s., Českobratrská 3321/46, 70200 Ostrava, Czech Republic \\ ${ }^{3} \mathrm{TaM}$, Technologie a Metalurgie, Areál VÚHŽ, a.s., 73951 Dobrá 120, Czech Republic \\ franek@opf.slu.cz
}

Prejem rokopisa - received: 2013-10-03; sprejem za objavo - accepted for publication: 2014-06-09

doi:10.17222/mit.2013.224

\begin{abstract}
The paper describes a determination of the cause of transverse internal cracks on a continuously cast slab using an analytical software tool, called LITIOS. It is a complex system based on long-term monitoring of the casting parameters and their impact on the quality of the slabs. Transverse internal cracks are characterised by identifying the possible causes of their origin. Using the LITIOS system, selected constant (invariable) and variable parameters of the casting were assigned to specific cracks and on their basis the causes of the cracks were determined.

Keywords: continuous casting of steel, slab, casting parameters, quality prediction, crack, software tool
\end{abstract}

Članek opisuje ugotavljanje vzrokov notranjih prečnih razpok v kontinuirno litem slabu z uporabo analitskega programskega orodja LITIOS. To je kompleksen sistem, ki temelji na dolgotrajnem nadzoru parametrov pri litju in njihovem vplivu na kvaliteto slabov. Ocenjene so prečne notranje razpoke s prikazom mogočih vzrokov za njihov nastanek. Z uporabo sistema LITIOS so bile dodeljene izbrane konstante (nespremenljivke) in spremenljivi parametri litja določeni razpoki in na tej osnovi so bili določeni vzroki za nastanek razpok.

Ključne besede: kontinuirno litje jekla, slab, parametri litja, napovedovanje kakovosti, razpoka, programsko orodje

\section{INTRODUCTION}

Continuous casting is a complex process, characterised by a considerable instability, i.e., by the so-called fluctuations. The fluctuations have a negative influence on the quality of slabs. To a large extent, they make it difficult to determine the causes of defects and, hence, also the optimum technological parameters for the casting process or their control during the events caused by the technology.

The whole process of casting steel is thoroughly mapped by measuring and reading the monitored data, including the chemical-analysis results. Quality ratings are assigned to the produced continuously cast slabs and to the products rolled from them. In this way, a timeline of very extensive data, mapping the production process is created. It can be, however, concluded that the potential of these data has not yet been sufficiently used. The reason this is, among other things, the fact that it is very difficult to handle these data and that assigning the data to the appropriate place on a slab and a possible defect is not easy. In spite of that, the operation of continuous casting, especially the casting of slabs, is nowadays practically impossible without the use of the systems for monitoring the casting parameters and the software systems for optimising the casting parameters.
An example of an artificial-intelligence technique for optimising the process parameters used for the continuous casting of steel is given $\mathrm{in}^{1}$. The mathematical modelling and optimisation strategy, genetic algorithm and knowledge base, applied to the continuous casting of steel are given $i^{2}$. A description of a properly developed algorithm solving an essential component of the above mentioned systems, including the assigning of the data to a specific place on the slab, is described in several works, e.g., in ${ }^{3}$. A multi-dimensional, statistical, model-based system for monitoring continuous casting and detecting the risk of impending breakouts is also the subject of the U.S. patent. ${ }^{4}$

Today, specialised companies offer different solutions for meeting the requirements for an ever increasing quality of steel, with simultaneous reductions in the manufacturing costs. For example, the company Siemens Metals Technologies provides the basic automation solutions for all the types of continuous-casting machines, i.e., for casting slabs, blooms, billets, the blanks for dog-bone sections (beam-blank casters) as well as for the equipment for producing endless strips. Sets of automation programs meet the requirements for the performance of production units, dimensional flexibility, the quality of semi-products and final products, and the maximum 
yield. Reference ${ }^{5}$ states that the described solutions were installed on hundreds of casting machines worldwide, in both the new and the existing plants.

An extensive and comprehensive range of optimisation processes, optimisation models, technology-management functions and services is crucial for meeting the production and quality goals. On-line data links for a continuous support provide a rapid system for modernisation, maintenance and metallurgical assistance. Referen$\mathrm{ce}^{5}$ also states that with the support of a vast experience the described packages combine excellent technology and automation solutions that perfectly control the process of continuous casting and its complex parameters.

\section{USE OF THE SYSTEMS FOR MONITORING THE PARAMETERS AND QUALITY PREDICTION}

The data obtained from the above-mentioned systems for monitoring the casting parameters and the software systems for optimising the casting parameters call for the use of advanced statistical methods for monitoring and evaluating the quality of continuously cast blanks ${ }^{6-8}$ and for the subsequent prediction of defects.

At present, it can be said that the basic technical development of the classical machines for continuous casting of steel has mostly reached such a level that a further development is often not necessary. Minor metallurgical, technical and technological improvements are naturally still ongoing in these areas, but, in general, it can be said that other possibilities for making the production more efficient through major changes are already limited by very narrow barriers.

One of the areas where some reserves still exist is increasing and control of the quality of continuously cast blanks and, particularly, the final products of a metallurgical plant. This can be achieved by introducing prediction systems, in the first stage, for predicting the quality of continuously cast blanks and then of the final products. According to the design of these systems their primary objective is to predict the quality of the products at the moment when they leave the production line, or even before it.

There is a possibility of a transition from a discontinuous production in the segment of liquid-steel rolled products to a continuous production, with evidenced savings, by eliminating the energy-intensive reheating before the next forming of the slabs. The prediction of quality allows another direct processing of the slabs without a significant risk that the absence of their control in the cold state, with the subsequent removal of the detected defects, will lead to a rejection or a quality degradation of the final products due to their defects. Even in the case of non-removable defects of the slabs, their rejection before the useless further processing is economically advantageous.

The second benefit of the prediction systems, which probably has not yet been sufficiently appreciated, is the use of the feedback between the quality of a slab and a final product, and the technological parameters for casting steel on a CCM, or the parameters for processing a continuously cast slab at a rolling mill. Archiving and statistical processing of the data describing these relations (the parameters versus the quality level) can provide, with a surprising success, the optimum technological parameters for casting and for further processing.

The methods for acquiring data and explaining their use in the metallurgical-industry operating conditions as a tool for improving the steelmaking processes, description of the basic processes and various approaches to the implementation of the necessary software tools, as well as data acquisition, creation of knowledge databases and their storing, displaying of the results and diagnostics all of these represent the essential activities and the segments of the developed software systems aimed at achieving the basic objective, i.e., an increase in the quality and in the yield of the production of steel products. ${ }^{9}$

\section{LITIOS SOFTWARE SYSTEM}

Within the research, under the support of various projects, in cooperation with technologists and metallurgists, numerous statistical analyses were made on the concrete CCM. The procedure and the obtained result for the specific defect are described below. This article describes the possibility to monitor dozens of the parameters that are assigned to any section of a cast slab. In the event that the Baumann sulphur print made on a transverse sample taken from a cast slab in the standard manner shows any defects, it is possible to assign certain casting parameters to this sample and compare them with the documented reality.

This procedure is then also the basic prerequisite for predicting the quality of cast slabs and, subsequently, of the sheets rolled from these slabs. If we assume, already at the general level, the knowledge about the qualitative relation between a casting parameter and a slab defect, this procedure is then used for confirming their relation. And, in the case of the limit values that differ between different CCMs, this procedure allows their exact determination. This makes it possible to express the basic result of a prediction with a YES-NO verdict about the presence of a defect.

Another necessary prerequisite for analysing the causes of defects in a slab is also the selection and assignment of the casting parameters to the place where these defects are formed. In the case of Baumann sulphur prints the above refers to the data assigned to the place, from which they were taken.

The company EVRAZ VÍTKOVICE STEEL, a. s., implemented an original complex system of long-term monitoring of the casting parameters and of their impact on the quality of the slabs, called LITIOS. ${ }^{3}$ This software system is organically linked with an on-line temperature 


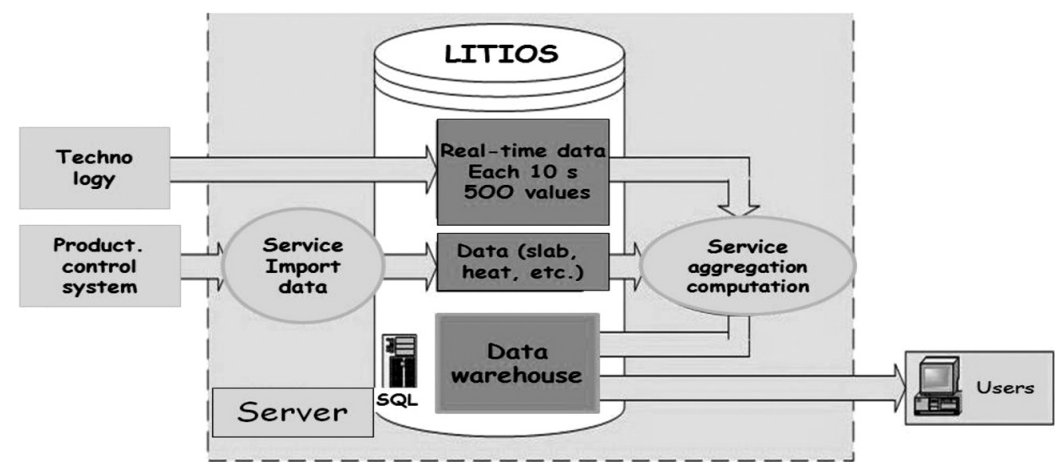

Figure 1: Architecture of the LITIOS monitoring system

Slika 1: Shema nadzornega sistema LITIOS

model, as well as with an on-line module of data acquisition. The system deals with all the data available from the CCM process. The system comprises the recording and filtering of the data, their sorting, entering into the relational database system, as well as the data aggregation and their graphical interpretation. Technological data, measured every 10 seconds, are entered from the temperature model. The software of the temperature model directly enters the data into the database of the LITIOS system. The LITIOS software system also records all the necessary data about each sequence of the superior system for the automatic control of the steel shop, called FLS, and it enters them into the database system. It enables a filtration of the data and performs the necessary data aggregation. This aggregation is necessary in order to simplify the work and handle large amounts of data. It turns out that it is appropriate and sufficient to aggregate the data per meter of the length of a casting strand. The developed software is modular, using the latest knowledge on the database technology and data-analysis methods. The system architecture is shown in Figure 1.

Data storage is performed according to the hierarchy of their formation: the data about the sequence, heat, slab, measured value (the so-called channels) of the continuous casting machine, the data about the quality of the slabs and the products rolled from them. The files are divided into items with their attributes. The whole system (Figure 1) thus contains approximately 500 items, and if we take into account that the technological parameters, the so-called channels, are measured every 10 seconds, we see that a very large amount of data is created.

The system provides reports and it is possible to view the data for individual sequences, heats and slabs. The selected data are represented graphically. Various selections of the data are available for the analytical methods. A user can transform the data into a matrix of the causes - the measured values and the consequences i.e., the quality indicators. The employees of a steel shop use these narrowed data analyses of the evolution of casting. The system allows an export of the selected data to the other statistical programs for more detailed analyses. The data from the LITIOS system were used for the analyses of the crack formation presented below.

\section{TRANSVERSE INTERNAL CRACKS}

These cracks, also called the half-way cracks because of their position on a slab cross-section, which are caused by straightening or bending, are situated between the surface and the centre of a slab, in the plane perpendicular to the direction of casting. They mostly occur in the top half of a slab cross-section. They are schematically illustrated in Figure 2.

In some cases transverse internal cracks in continuously cast slabs may cause a deterioration of the utility properties of the heavy plates rolled from them, or possibly even their rejection from the production as a result of an ultrasonic inspection. The best prevention against these undesirable phenomena during the production of heavy plates is an elimination of these cracks already during the continuous casting of slabs on a CCM.

The basic causes of the formation of these cracks are high tensile deformations in the high-temperature zone of low strength and ductility. The formation of these deformations is explained with three different facts ${ }^{10}$ :

- intensive secondary cooling, which causes high-temperature reheating of the surface of a continuously cast slab

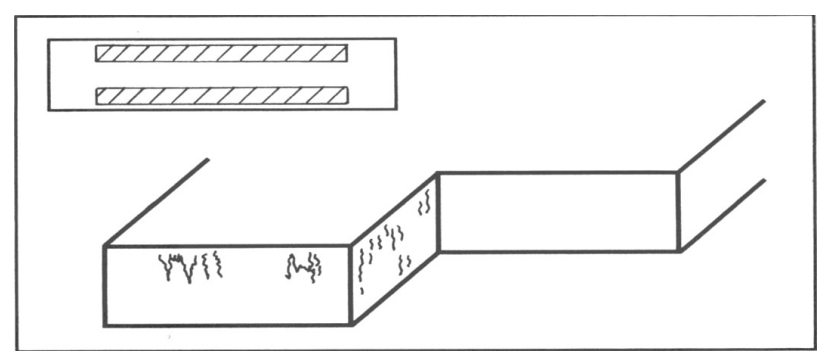

Figure 2: Schematic illustration of transverse cracks and localisation of their occurrence in the transverse and longitudinal sections of a continuously cast slab

Slika 2: Shematski prikaz prečnih razpok in mesto njihove pojave na prečnem in vzdolžnem prerezu kontinuirno litega slaba 


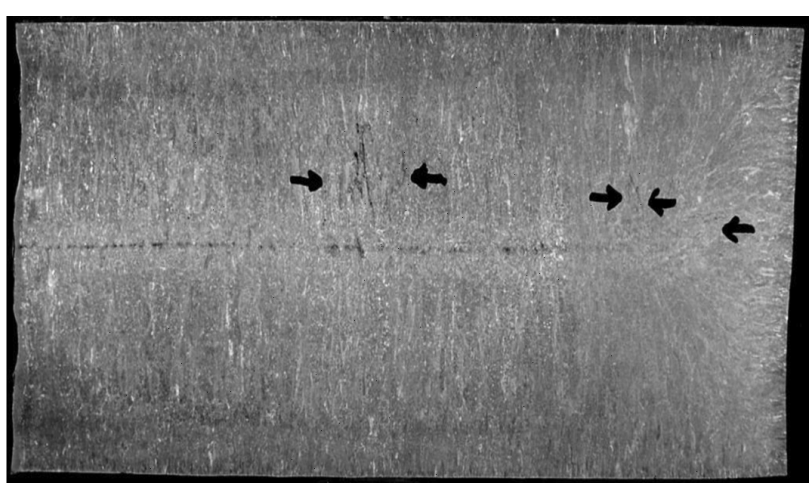

Figure 3: Transverse internal cracks in the top half of a macro-etched slab sample; example from the catalogue of defects

Slika 3: Notranje prečne razpoke v gornji polovici makro jedkanega vzorca slaba; primer iz kataloga napak

- a depression of the wide side of a slab

- slab bending and straightening, particularly in the temperature interval of the reduced strength and ductility of steel, i.e., within the temperature interval from $950{ }^{\circ} \mathrm{C}$ to $700{ }^{\circ} \mathrm{C}$

In addition to the usual sensitivity of some steel grades to the formation of these cracks, there are also some other technological parameters that contribute to the formation of transverse cracks:

- a high casting temperature, causing a wide zone of a columnar casting structure, sometimes taking place even after the transcrystallisation

- a low casting rate, causing a reduction in the slab temperature in the area of its straightening

- a high casting rate

- a drastic increase in the cooling intensity after the exit of a slab from the mould

- a chemical composition of steel; micro-alloyed steels are particularly susceptible to the formation of these cracks since micro-alloying elements, namely, vanadium, titanium, niobium, etc., reduce the ductility of steel exactly at the critical temperatures of the slab straightening.

When inspecting the causes of the formation of transverse intermediate cracks we see an obvious antagonism of the influence of the secondary cooling on the formation of these defects. The so-called soft cooling is required, which causes a hotter and thinner strand shell leading to a lower resistance to depression. The compromise must be, therefore, the optimum intensity of the cooling.

In the case of a formation of the cracks caused by slab bending and straightening, it is probable that a more important role is played by the straightening, indicated by the fact that the cracks are almost always situated in the top part of a slab, i.e., in the half of the cross-section belonging to the smaller radius of bending. This defect cannot be removed. If it is situated at a sufficient depth under the slab surface and if further processing of the slab is not too demanding, this defect need not present a cause of difficulties during such processing or a cause of a lower quality of the plate.

A determination of the presence and form of transverse cracks as well as their quantification according to the methodology used in the given case are performed in the standard manner on macro-etches and/or on Baumann sulphur prints. Figure 3 shows an example of such manifestations of transverse cracks.

\section{DETERMINATION OF THE CAUSES OF CRACK FORMATION}

For a determination of the cause, or causes, of the formation of internal transverse cracks on the concrete slab we first chose the parameters that might have caused the defect. With the LITIOS analytical software tool we then assigned the values of the selected casting parameters to the evaluated sample and compared these values with the values defined, in the standard manner, for the given CCM as satisfactory, i.e., with the limits specified by the supplier of the equipment or by the CCM operator on the basis of long-term experience.

For an exploration of the causes of the internal transverse cracks in the specific slab we chose the heat and the sample that was subjected to a metallographic evaluation.

A transverse sample was taken, i.e., a sample from the plane perpendicular to the direction of casting. The sample was cut with oxygen-acetylene flame at the end of the cooling bed. For a determination of the possible degree of defects the sample was then polished in a metallographic laboratory, etched in order to see the nature of the macrostructure and then Baumann sulphur prints were made. The evaluation presented in the table below was carried out according to the commonly used standard methodology for evaluating cast slabs.

Table 1 below presents the degrees of defects determined on the Baumann print in the metallographic testing laboratory.

Transverse internal cracks were visible on the sample. Using a 6-degree scale, from degree 0 denoting no defect to degree 5 denoting the largest defect, we determined the cracks of the $3^{\text {rd }}$ degree, which already exceeded the limit of the harmlessness of the defect, see the Baumann sulphur print in Figure 4.

Table 1: Evaluation of defects on the sulphur print

Tabela 1: Stopnje napak, določene na Baumannovem odtisu v metalografskem laboratoriju

\begin{tabular}{|c|c|c|c|c|c|c|c|}
\hline Defect & $\begin{array}{c}\text { Point } \\
\text { inclusions }\end{array}$ & $\begin{array}{c}\text { Cluster } \\
\text { inclusions }\end{array}$ & $\begin{array}{c}\text { Central } \\
\text { segregation }\end{array}$ & Lateral cracks & Corner cracks & $\begin{array}{c}\text { Transverse } \\
\text { internal cracks }\end{array}$ & $\begin{array}{l}\text { Longitudinal } \\
\text { internal cracks }\end{array}$ \\
\hline Degree & 2 & 0 & 2 & 2 & 0 & 3 & NA \\
\hline
\end{tabular}




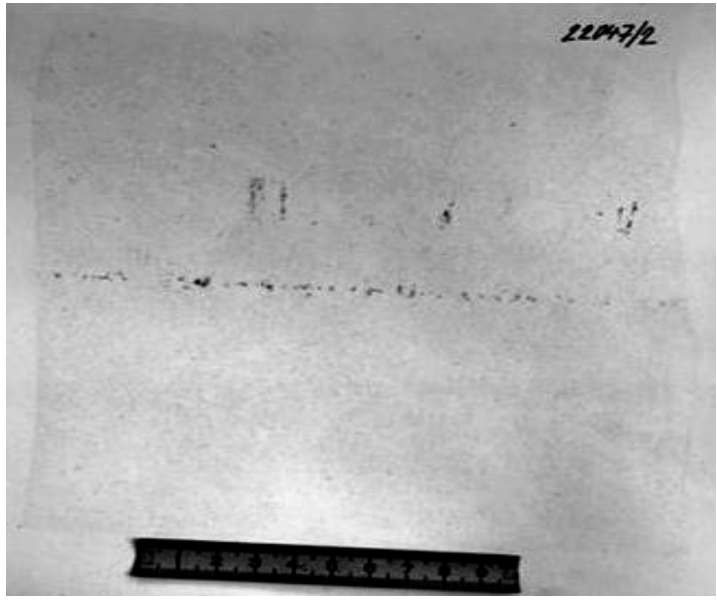

Figure 4: Transverse internal cracks on the sulphur print of the investigated sample

Slika 4: Prečne notranje razpoke na Baumannovem odtisu preiskovanega vzorca

The investigated heat and slab were produced using the following "fix" technical parameters that did not change during the casting of the given heat:

- Steel grade - low-carbon, micro-alloyed with vanadium, titanium and niobium

- Chemical composition - $0.06 \%$ C, $1.66 \% \mathrm{Mn}, 0.30$ $\% \mathrm{Si}, 0.016 \% \mathrm{P}, 0.005 \% \mathrm{~S}, 0.02 \% \mathrm{~V}, 0.03 \% \mathrm{Nb}$, $0.005 \% \mathrm{Ti}$

- Liquidus temperature $-1516{ }^{\circ} \mathrm{C}$

- Slab dimensions - $180 \mathrm{~mm} \times 1580 \mathrm{~mm}$

The values of the variable casting parameters presented in Table 2 and assigned to the exactly defined section of the slab, from which the sample was taken for a metallographic investigation, were the following:

Only one parameter, which directly specifies the degree of failure of its stipulated value, is contained in the values presented in this table. It is the non-achievement of the minimum casting rate specified by the technological standard. In the investigated heat it was necessary to reduce the casting rate on the upstream units due to technological causes. For a possible comparison with the state before the slowdown of the casting rate and for an evaluation of a possible influence of the deviations of the values of individual parameters, we give, in the last row of the table, the average values of the monitored parameters, acquired from approximately 250 heats of the same slab format and the same steel grade.

\section{RESULTS AND DISCUSSION}

On the basis of the presented values of the selected casting parameters and the occurrence of the internal transverse cracks on the slab it is possible to draw rather unequivocal conclusions:

- The cause of the internal transverse cracks in the specific slab represented by a sample of the Baumann sulphur print and macro-etching, was a reduction in the casting rate. The value of the casting rate specified by the technological standard for the given steel grade of $1.20 \mathrm{~m} / \mathrm{min}$ was reduced down to 0.74 $\mathrm{m} / \mathrm{min}$, indicating the overall drop in the casting rate by $38 \%$.

- The reduction in the casting rate is also documented in the system of prediction by the monitored parameter of the non-achievement of the minimum casting rate - the value recorded in our case was minus $470 \mathrm{~mm}$.

- The reduced casting rate entailed a reduction in the surface temperature of the measured planes of the secondary cooling and, consequently, also a reduction in the density of the heat flux from the slab into the cooling media. Particularly the reduction in the surface temperature of the slab in the area of its straightening might have been the primary cause of the transverse cracks.

- The steel grade also played its unfavourable role during the formation of the investigated cracks. Namely, the micro-alloying elements - vanadium, niobium and titanium - reduce the steel ductility already at approximately $950{ }^{\circ} \mathrm{C}$. They form the so-called "trough" of the ductility reduced below this temperature value, which means that micro-alloyed steels are here more susceptible to a crack formation in continuously cast products.

The paper describes one of the possible approaches of using the prediction system, or using the values of the casting parameters selected for this system, for an exact determination of the causes of the transverse internal cracks on a concrete slab. In the professional literature, we did not find any solutions or results for exactly this, or a similar, problem. On the other hand, it is possible to find studies or articles dealing with a prediction system and the use of this software as an analytical tool for an assessment of the continuous casting process and the quality of cast blanks.

Table 2: Values of the parameters for the investigated sample and the average values for 250 heats

Tabela 2: Vrednosti parametrov preiskovanih vzorcev in povprečne vrednosti iz 250 šarž

\begin{tabular}{|c|c|c|c|c|c|c|}
\hline Parameter & $\begin{array}{l}\text { Casting rate } \\
\left(V_{\mathrm{g}}\right) /\left(\mathrm{m} \mathrm{min}^{-1}\right)\end{array}$ & $\begin{array}{l}V_{\mathrm{g}} \text { below the } \\
\text { minimum limit } \\
V_{\mathrm{g}} /\left(\mathrm{mm} \mathrm{min}^{-1}\right)\end{array}$ & $\begin{array}{l}\text { Overheating of } \\
\text { steel above Tl in } \\
\text { the tundish } \\
\left({ }^{\circ} \mathrm{C}\right)\end{array}$ & $\begin{array}{c}\text { Type Seg } 6 \\
\left({ }^{\circ} \mathrm{C}\right)\end{array}$ & $\begin{array}{c}\text { Type Seg } 11 \\
\left({ }^{\circ} \mathrm{C}\right)\end{array}$ & $\begin{array}{c}\text { Heat-flux } \\
\text { density } \\
\left(\mathrm{W} \mathrm{m^{-2 }}\right)\end{array}$ \\
\hline Value & 0.74 & -470 & 35 & 915 & 842 & 989705 \\
\hline Average for 250 & 1.19 & 3 & 33 & 965 & 876 & 1086773 \\
\hline
\end{tabular}




\section{Z. FRANĚK et al.: DETERMINATION OF THE CAUSE OF THE FORMATION OF TRANSVERSE INTERNAL CRACKS ...}

Their results are generally comparable with the use of the LITIOS analytical software tool, presented here. They are presented, for example, in ${ }^{11}$, which describes the strategies and methods for monitoring and controlling the quality during the production of flat steel. It gives a complete description of the quality, technological parameters and information technology. The data are archived and used in an appropriate manner for intervening at a specified place in order to improve the quality. The percentage of success is said to be $85 \%$. Reference $^{12}$ gives an example of a complex system integrated in CSP at the ACB company, including the modules that collect and process the data, search and visualise them, draw up statistics and analyse the phenomena. Individual, special cases can be quickly solved with the use of this software.

\section{CONCLUSIONS}

The cause of the transverse internal cracks in a continuously cast slab was determined with a complex system of a long-term monitoring of the casting parameters using the LITIOS analytical software tool:

- In a metallographic laboratory a cross-section sample taken from a continuously cast slab was evaluated. Some transverse internal cracks were found on it at a degree exceeding the harmlessness of such a defect.

- The technologist determined the possible technological parameters of the casting that might have caused these cracks.

- Subsequently, using the LITIOS analytical software tools, we assigned concrete variable casting values, corresponding exactly to the taken sample, to these parameters.

- Only one technological parameter was found to be beyond the standard limits set for casting the relevant steel grade.

This analysis clearly revealed the cause of the examined cracks. It was the forced reduction in the casting rate to approximately $62 \%$ of the value specified by the standard technological procedure.

By using a similar procedure it is possible to determine the technological cause of any defect found on the Baumann sulphur print or on a macro-etched sample taken from a continuously cast slab, and to perform interventions aiming at controlling the casting techno- logy, leading to a minimisation or complete elimination of the causes of the defect during the subsequent casting.

By using the LITIOS software tool, together with examining the samples and determining their exact evaluation in the metallographic laboratory, we can efficiently contribute to improving the quality of cast slabs and, ultimately, to increasing the efficiency of the final products made from them.

\section{REFERENCES}

${ }^{1}$ C. A. Santos, J. A. Spim, M. C. Flerardi, A. Garcia, The use of artificial intelligence technique for the optimisation of process parameters used in the continuous casting of steel, Applied Mathematical Modelling, 26 (2002) 11, 1077-1092, doi:10.1016/s0307-904x(02) 00062-8

${ }^{2}$ C. A. Santos, J. A. Spim, A. Garcia, Mathematical modelling and optimization strategies (genetic algorithm and knowledge base) applied to the continuous casting of steel, Engineering Applications of Artificial Intelligence, 16 (2003) 5-6, 511-527, doi:10.1016/ S0952-1976(03)00072-1

${ }^{3}$ F. Kavička, Z. Franěk, J. Štětina, Software Analytical Instrument for Assessment of the Process of Casting Slabs, Proceedings of the 10th International Conference on Numerical Methods in Industrial Forming Processes NUMIFORM 2010, Pohang, Republic of Korea, 2010, 586-592, doi:10.1063/1.3457607

${ }^{4}$ V. Vaculik, R. B. MacCuish, R. K. Mutha, Multivariate statistical model-based system for monitoring the operation of a continuous caster and detecting the onset of impending breakouts, US Patent 6564119,2003

${ }^{5}$ Electrics and Automation for Continuous Casting - SIMETAL CC Control, Basic automation, Metals magazine, 1 (2014)

${ }^{6}$ J. Štětina, Z. Franěk, F. Kavička, M. Masarik, V. Krol, Quality Optimization of Casting Slab via Mathematical and Statistical Method, DVD Proceedings of the 7th European Continuous Casting Conference METEC InSteelCon, Düsseldorf, Germany, 2011, 193-200

${ }^{7}$ T. Mauder, C. Sandera, J. Stetina, M. Seda, Optimization of The Quality of Continuously Cast Steel Slab Using the Firefly Algorithm, Mater. Tehnol., 45 (2011) 4, 347-350

${ }^{8}$ T. Mauder, Z. Franek, F. Kavicka, M. Masarik, J. Stetina, A Mathematical \& Stochastic Modelling of the Concasting of Steel Slabs, Proceedings of the 18th International Conference on Metallurgy and Materials, Hradec nad Moravici, 2009, 41-48

${ }^{9}$ A. Ebel, J. Hackmann, N. Holzknecht, N. Link, H. Peters, Industrielles data mining in der stahlindustrie, Stahl und Eisen, 132 (2012) C.2, 29-37

${ }^{10}$ J. Šmíd, Catalogue of defects of continuously cast slabs, Technologie und Metallurgie, Ltd., Business Studies, 2011, 125 p.

${ }^{11}$ H. Peters, T. Heckenthaler, N. Holzknecht, Strategies and methods for quality monitoring and quality control in flat steel production, Stahl und Eisen, 126 (2005) C.7, 29-36

${ }^{12}$ M. Reifferscheid, J. Kempken, M. Bruns, J. I. L. Garcia-Echave, J. M. Ovejero, Integrated Product Improvement by Quality Analysis and Modelling, Stahl und Eisen, 125 (2005) 12, 29-34 